\title{
Müller's Duct Persistence Syndrome Associated with Cryptorchidism, Sertoli Cell Tumor and Pyometra in a Miniature Schnauzer
}

\author{
Tais Teixeira Zambarda' ${ }^{1}$, Renata Queiroz Stefani² ${ }^{2}$ Luciana Sonne $^{3}$ \& Álan Gomes Pöppl ${ }^{4}$
}

\begin{abstract}
Background: Sexual development disturbances (SDD) are divided in SDD with XX genotype (SDD XX) and SDD with XY genotype (SDD XY). Among SDD XY, the Müller's duct persistence syndrome (MDPS) is characterized by XY karyotype individuals with male external genitals; however, with internal female reproductive organs such as uterine horns, uterus, and cranial vagina portion. The MDPS cases and their related complications are considered very rare in veterinary medicine. The aim of the present case report is to describe the clinical and pathological aspects of a MDPS case associated with cryptorchidism, Sertoli cell tumor, and pyometra in a Miniature Schnauzer dog.

Case: A 7-year-old male Miniature Schnauzer weighting $7 \mathrm{~kg}$ was brought to veterinary consultation due to owner's complain of frequent vomiting, apathy, abdominal algia and progressive scrotal enlargement in the last two months. Physical exam reveals hyperthermia $\left(39.7^{\circ} \mathrm{C}\right)$, discrete dehydration, enlarged popliteal lymph nodes as well as scrotum enlargement with only one palpable testicle. A blood sample collected for complete blood count showed regenerative anemia, thrombocytopenia, and neutrophilia with left shift in the leukogram. Abdominal ultrasound examination indicated the presence of a tubular structure filled by anechoic content extending from the scrotum to caudal abdomen. Moreover, a 6.39 x 8.54 $\mathrm{cm}$ heterogeneous mass in the medial mesogastric region became evident. The patient was hospitalized and submitted to exploratory laparotomy after $24 \mathrm{~h}$ due to rectal temperature increase $\left(41^{\circ} \mathrm{C}\right)$, worsened abdominal pain, and intense apathy. There was free purulent liquid in abdominal cavity and two uterine horns were documented. The left uterine horn passes through inguinal ring and both horns were filled by purulent material. At the right uterine horn extremity there was the mass previously document at ultrasound. The structures were removed and sent to histopathological examination. The microscopic exam confirmed testicular and uterine tissue; furthermore, a Sertoli cell tumor and pyometra were also characterized. The dog was kept at the hospital receiving fluid, antibiotics, analgesics, and anti-inflammatory therapy. After five days the animal was discharged with clear clinical recover. A sample for karyotyping was collected from the oral mucosa which reveals a XY karyotype in the dog. By this way it was concluded that the dog suffers from a SDD XY with MDPS associated to cryptorchidism, Sertoli cell tumor and pyometra.

Discussion: The MDPS cases are often associated with cryptorchidism and testicular tumors. Miniature Schnauzers is one of the most affected dog breeds with this condition, and the heritability pattern is already described. Most cases are identified in adult to old-aged dogs after vague clinical signs investigation such as apathy, anorexia and abdominal or inguinal enlargement, as observed in the present report. When Sertoli cell tumor are present, the hormone secretion pattern of this neoplasia may influence complications occurrence. Once higher estrogen levels may induce endometrial gland proliferation, hydrometra and pyometra are among these complications, as well as reduced hematopoiesis. Moreover, progesterone levels could be also increased favoring pyometra pathophysiology. By conclusion, despite very rare, MDPS should be investigated in Miniature Schnauzers with vague clinical signs, especially cryptorchidic ones. Karyotyping and histopathology were crucial to confirm the diagnosis. Moreover, no other case with MDPS, cryptorchidism, Sertoli cell tumor, and pyometra was found in the published literature consulted.
\end{abstract}

Keywords: sexual development disturbance, pseudo hermaphroditism, karyotyping, testicular tumor. 


\section{INTRODUCTION}

Reproductive system anomalies may have genetic basis, may originate during gonadal development, and lastly, can result from tubular genital differentiation abnormalities [14]. Intersexuality refers to reproductive system development alterations that oppose to the characteristics determined by genetic sex [8]. The sexual development disturbances (SDD), as are called the intersex cases, are divided in SDD with XX genotype (SDD XX) sexual chromosomic or XY genotype (SDD $\mathrm{XY}$ ). Those SDD XX and $\mathrm{XY}$ are subdivided in groups accordingly to gonadal type present [4].

Among the SDD XY there are the Muller's duct persistence syndrome (MDPS), in which XY karyotype individuals, externally seemly like healthy males, with outside male genitals associated with unilateral or bilateral cryptorchidism; however, internally they have uterine tubes, uterus, and vaginal cranial portion [14]. This anomaly occurrence is reported mainly in Miniature Schnauzer breed were MDPS is the result of a recessive autosomal gene with a heritability pattern $[3,4,9]$. Complications such as hydrometra, pyometra, prostatitis, urinary tract infection, and neoplasia are often reported associated with MDPS [4,14,15,20].

The MDPS' cases are considered very rare in veterinary medicine, as well as the related complications $[4,13,14]$. The purpose of this work is to describe clinical and histopathologic aspects of MDPS associated with Sertoli cell tumor and pyometra in a Miniature Schnauzer.

\section{CASE}

A 7-year-old male Miniature Schnauzer weighting $7 \mathrm{~kg}$ was brought to veterinary consultation at the Hospital de Clínicas Veterinárias from the Universidade Federal do Rio Grande do Sul due to owner's complain of frequent vomiting, apathy, abdominal algia and progressive scrotal enlargement in the last two months (Figure A\&B). The owners also reported that despite entire male, the dog never breeds or had sexual interest for females in the heat. At physical exam the patient showed hypocolored mucosa membranes, reactive popliteal lymph nodes, and $39.7^{\circ} \mathrm{C}$ rectal temperature. The dog has only one testicle palpable; however, the scrotum was enlarged, increased temperature, and with a tubular format that addressed towards the abdominal left side. The penis was carefully examined, and no abnormalities were documented macroscopically. The blood work (Table 1) showed discrete regenerative anemia associated with anisocytosis, macrocytosis, and hypochromia. Platelets count's was also reduced and there was a left shift leukogram. From the biochemical parameters analyzed only hypoalbuminemia rather hyper total proteinemia was noteworthy $[5,17]$. At ultrasound examination a tubular image filled by anechoic material extending from the scrotum into caudal abdomen was saw. Moreover, a 6.39 x $8.54 \mathrm{~cm}$ heterogeneous mass with mix echogenicity was documented at medial mesogastric region. No other abnormalities in abdominal cavity were reported.

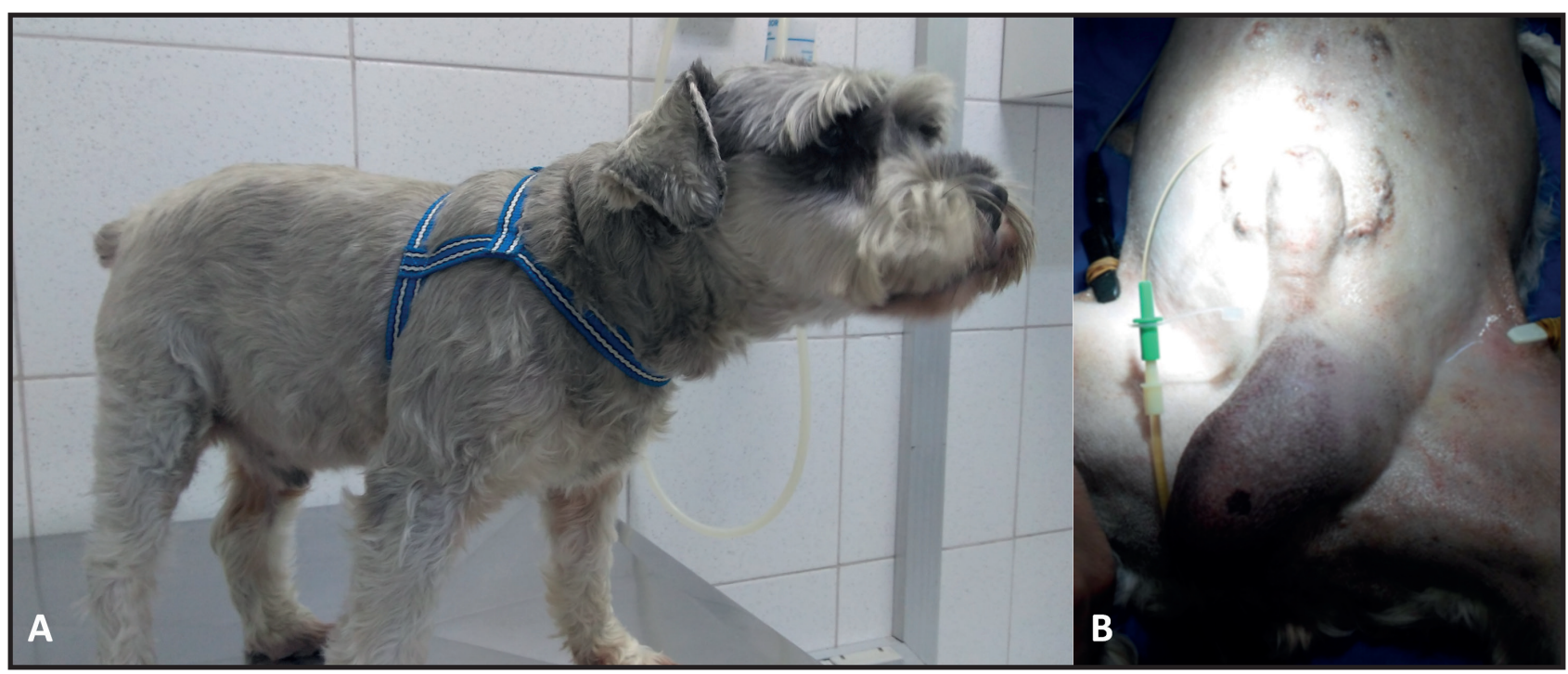

Figure 1. A- Dog's general view. A discrete potbelly appearance is evident due to pyometra and Sertoli cell tumor in the cryptorchidic testicle. B- Presurgical patient's ventral view. The penis is evident, and the scrotum assumed a tubular enlarged format secondary to the left uterine horn filled with purulent secretion passing through the inguinal ring. 
Table 1. Complete blood count and serum biochemical parameters analyzed at the first consultation and the evolution $24 \mathrm{~h}$ after surgery.

\begin{tabular}{cccc}
\hline Parameter & Initial consultation & 24 h after surgery & Reference Interval [5,17] \\
\hline Eritrocytes $\left(\mathrm{x} 10^{6} / \mu \mathrm{L}\right)$ & 2.64 & 3.24 & $5.5-8.5$ \\
Hemoglobin $(\mathrm{g} / \mathrm{dL})$ & 7.4 & 8.4 & $12-18$ \\
Hematocrit $(\%)$ & 25 & 27 & $37-55$ \\
Total Leukocytes $\left(\mathrm{x} 10^{3} / \mu \mathrm{L}\right)$ & 12.72 & 11 & $6-17$ \\
Rod neutrophils $\left(\mathrm{x} 10^{3} / \mu \mathrm{L}\right)$ & 1.89 & 0.44 & $0-0.3$ \\
Targeted neutrophils $\left(\mathrm{x} 10^{3} / \mu \mathrm{L}\right)$ & 7.81 & 8.58 & $3-11.5$ \\
Eosinophils $\left(\mathrm{x} 10^{3} / \mu \mathrm{L}\right)$ & 0.25 & 0.22 & $0.1-1.25$ \\
Basophils $\left(\mathrm{x} 10^{3} / \mu \mathrm{L}\right)$ & 0 & 0 & Rare \\
Monocytes $\left(\mathrm{x} 10^{3} / \mu \mathrm{L}\right)$ & 0.12 & 0.11 & $0.15-1.35$ \\
Limphocytes $\left(\mathrm{x} 10^{3} / \mu \mathrm{L}\right)$ & 2.64 & 1.65 & $1-4.8$ \\
Total Plasmatic Protein $(\mathrm{g} / \mathrm{L})$ & 102 & 78 & $60-80$ \\
Platelets $\left(\mathrm{x} 10^{3} / \mu \mathrm{L}\right)$ & 140 & 150 & $200-500$ \\
Albumin $(\mathrm{g} / \mathrm{L})$ & 21 & $*$ & $26-33$ \\
ALT $(\mathrm{UI} / \mathrm{L})$ & 43 & $*$ & $<102$ \\
Creatinin $(\mathrm{mg} / \mathrm{dL})$ & 0.73 & 0.65 & $0.5-1.5$ \\
\hline
\end{tabular}

*Parameters not evaluated in this exam. ALT: alanine-amino transferase.

Due to patient's clinical picture the animal was hospitalized for fluid therapy stabilization (Ringer lactate solution ${ }^{1} 80 \mathrm{~mL} / \mathrm{kg} /$ day) prior exploratory laparotomy. The dog was also medicated with Dipyrone ${ }^{2}$ (25 mg/kg, three times a day, IV), Ceftriaxone ${ }^{3}(30 \mathrm{mg} /$ $\mathrm{kg}$, three times a day, IV), and Metronidazole ${ }^{4}(15 \mathrm{mg} /$ $\mathrm{kg}$, twice times a day, IV). After $24 \mathrm{~h}$ hospitalization a worse clinical response was perceived with aggravated abdominal algia, intense apathy, and rectal temperature elevation to $41^{\circ} \mathrm{C}$. A second abdominal ultrasound examination showed free liquid within the abdomen. During the laparotomy a huge amount of purulent abdominal liquid was visualized. Adjacent to the urinary bladder, a distended structure like a uterus was observed filled with purulent secretion. A cervix, cranial vaginal portion, and two uterine horns caudally displaced were identified where the left horn passes through inguinal canal. In the right uterine horn extremity, there was a mass with about $8 \mathrm{~cm}$ diameter (Figure $2 \mathrm{~A}$ ). These structures were exerted and stored in Formalin solution $10 \%{ }^{5}$ until histopathological analysis.

Abdominal cavity was rinsed with warm Saline solution $(\mathrm{NaCl} 0,9 \%)^{1}$ and later standard inguinal canal and abdomen suture was made. The dog was kept hospitalized and medicated with the same drugs introduced before surgery plus Enrofloxacin ${ }^{6}(5 \mathrm{mg} / \mathrm{kg}$, twice times a day, IV), $\operatorname{Tramadol}^{7}(4 \mathrm{mg} / \mathrm{kg}$, three times a day, SC), and Omeprazol ${ }^{8}(1 \mathrm{mg} / \mathrm{kg}$, once daily, IV). The fluid therapy was adjusted to $60 \mathrm{~mL} / \mathrm{kg} / \mathrm{day}$.

The excised material was sent to the animal's pathology laboratory for further evaluation and confirmation that it was a uterus with two horns filled by liquid purulent secretion with some whitish lumps. In the left horn extremity, a $1.5 \times 1.0 \mathrm{~cm}$ stunted testicle with a white jelly like cystic structure was observed. The histopathological evaluation of this testicle showed up reduced germinative cell number, spermatozoid absence, macrophages, and neutrophilic lymphocytic infiltrated around vessels. Furthermore, in the right uterine horn extremity, an $8.0 \times 9.4 \times 5.0 \mathrm{~cm}$, firm and encapsulated neoplastic testicle was found. Microscopically, this structure showed neoplastic proliferation organized in tubules streaky by a moderate fibrous stroma. The cells were elongated with a fine eosinophilic cytoplasm, rounded nucleus with disperse to dotted chromatin, and evident nucleolus. There were also moderate anisocytosis and discrete anisocariosis with rare mitosis, characterized as a Sertoli tumor (Figure 2B). Uterine epithelium and submucosa showed accentuated neutrophilic and plasmocytic infiltrated and some macrophages which was considered as pyometra (Figure 2C). 


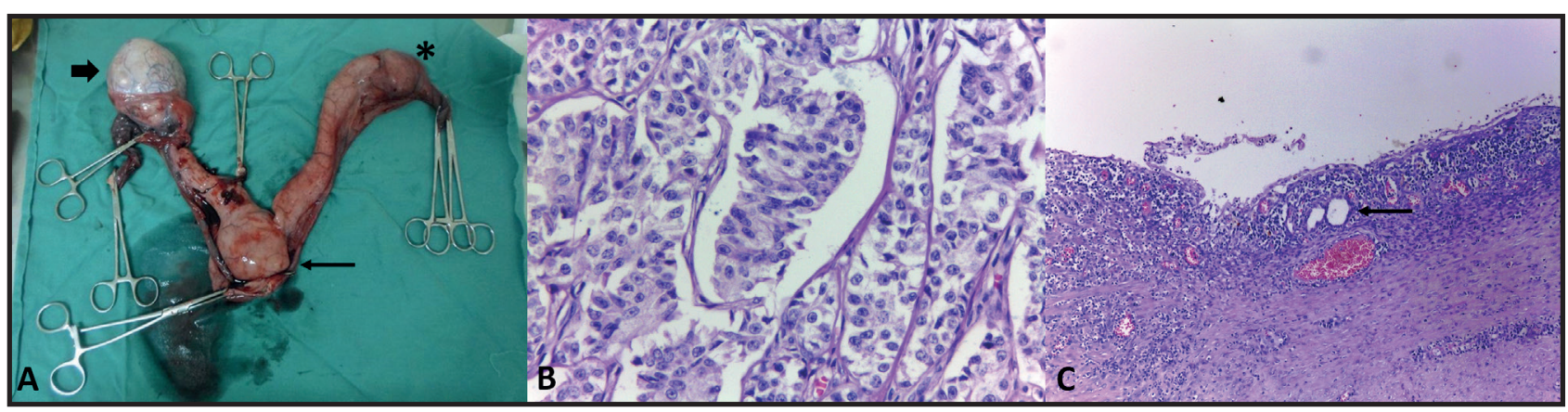

Figure 2. A- Uterus filled with purulent secretion removed from the patient (soft arrow). Cranial to the right uterine horn there was a $8.0 \mathrm{x} 9.4 \mathrm{x} 5.0 \mathrm{~cm}$ firm and neoplastic testicle (heavy arrow), while at the top of the left uterine horn a soft and stunted testicle was observed (asterisk). B- Right testicle showing Sertoli cell neoplastic infiltrate [HE; Obj 40x]. C- Uterine mucosa and submucosa microscopic appearance with accentuated inflammatory cell infiltrate predominantly neutrophils. There was absent of evident endometrial gland hyperplasia (soft arrow) [HE; Obj 20x].

Two days after the surgical procedure the patient showed marked clinical improvement, that was also observed in the blood work results $24 \mathrm{~h}$ after surgery (Table 1). On the fifth day after surgery the patient received hospital discharge under the same drug protocol; however, dipyrone and tramadol were kept for more three days, while omeprazole and enrofloxacin for more ten days. At the clinical review for surgical stitches removal, the patient was showing good clinical response, also observed in the blood work results $24 \mathrm{~h}$ after surgery. A cellular sample from the oral mucosa was collected with a sterile specific brush for karyotyping and DNA analysis. The result of this analysis reveals a XY karyotype, characterizing an SDD XY with related MDPS.

\section{DISCUSSION}

Individuals with a male external phenotype with a XY genotype and male gonadal tissue (testicles); but however, show female reproductive tract phenotypic characteristics such as tubular organs - as the case described herein - have SDD XY, elderly called male pseudo hermaphroditism [14]. Some crucial factors must to be present for the male phenotype development. The anti-Müllerian hormone (AMH) secreted by the Sertoli cells determine Müllerian's duct regression. While this, Leydig interstitial cells produce and secrete testosterone and the insulin-like growth factor-3 (IGF-3) which contributed to female differentiation inhibition and induce prostate, bulbourethral glands, penis and scrotum development [4]. Cases of SDD XY may occur by two different mechanisms: 1) androgendependent masculinization failure, and 2) MDPS [3]. Dogs with this syndrome shows structural gene mutation on the AMH receptor resulting in hormone action resistance $[14,15]$.
Most MDPS cases are identified in adult to old-aged dogs due to unspecific clinical signs that may be perceived by the owners such as apathy, anorexia, and abdominal or inguinal enlargement $[1,11,13,19,20]$ as reported in the present case. Cryptorchidism is often reported in the MDPS cases $[4,11,13]$. When this abnormality is related to MDPS cases, potentially is the result of interference in the first phase of testicular scrotal migration, which is controlled by AMH. Testicular tumors occurrence, specially Sertoli cell tumor are also common in these cases [13,14]. There is a case description of simultaneous Sertoli cell tumor and Leydig cell tumor in a male pseudo hermaphrodite patient [1]. Cryptorchidic dogs show testicular tumors more often in the right testicle as observed in the case reported herein [7].

Dogs that developed MDPS and Sertoli cell tumor can have increased serum estradiol levels secondary to the hyperestrogenism resultant of the tumor hormone activity, despite testosterone levels within reference range $[7,13]$. It is supposed that femininization clinical evidences correlate better with reduced serum testosterone to estradiol ratio, and not just with serum estradiol increasing. Once no hormonal measurements were taken from this patient, the hypothesis that the Sertoli tumor secrete estradiol or other estrogens could not be proved. However, this possibility raised because the patient showed thrombocytopenia, and there was contralateral testicular atrophy, common complications related to hyperestrogenism [7]. Moreover, progesterone serum measurement would be also of interest due to pyometra occurrence, a condition typically progesterone mediated. Furthermore, when pyometra is preceded by endometrial hyperplasia, estrogens are also involved in endometrial proliferation [18]. However, 
histopathological evaluation of the uterus does not support cystic endometrial hyperplasia preceding pyometra.

The patient from the present report showed macrocytic hypochromic anemia, a regenerative pattern, differently of the anemia pattern estrogen associated. This finding potentially is related to pyometra, secondary to chemical and bacterial lysine's associated with the uterine infection $[6,17,18]$. Nevertheless, the left shift documented in the leukogram refers to acute infection or septicemia, reinforcing the pyometra seriousness in the present case [2,12]. Likewise, hypoalbuminemia associated with globulin elevation as also observed in the present case also suggest inflammatory or septic conditions [5]. The improvement of these parameters after surgery and antibiotic therapy argues in favor of this hypothesis. Moreover, the presence of purulent free liquid within the abdomen and uterus gives more subsides to the pyometra inflammation and sepsis repercussions observed [18].

Pyometra occurrence associated with sertolioma in a dog with MDPS was previously reported; however, this case does not have cryptorchidism [19]. Once in the MDPS the testicles are connected to uterine cranial extremities, the migration of one or both gonads to scrotum causes uterine horn traverse over inguinal ring as observed during laparotomy [14].

Patient's karyotype study in these cases are fundamental to confirm a MDPS diagnosis. This anomaly has a genetic character in Miniature Schnauzer dogs, and its expression is limited to homozygotes
$[3,14,15]$. A molecular diagnostic test was developed for MDPS screening [16] which can identify male or female carriers allowing elimination of these patients from reproductive programs, and eventually, eliminate this mutation from Miniature Schnauzer dogs.

This report concludes that MDPS should be investigated and considered a possible diagnosis specially in cryptorchidic Miniature Schnauzer dogs. Moreover, no other case report was found in the literature reporting simultaneous Sertoli cell tumor, pyometra, and cryptorchidism occurrence in a dog with MDPS. This syndrome manifests by vague clinical signs, and histopathological exam, as well as karyotyping, were extremely important to confirm this diagnosis. Molecular screening test application would help to reduce occurrence of this anomaly.

\section{MANUFACTURERS}

${ }^{1} \mathrm{JP}$ Farma. Campinas, SP, Brazil.

${ }^{2}$ Legrand Pharma. Campinas, SP, Brazil.

${ }^{3} \mathrm{ABL}$ - Antibióticos do Brasil Ltda. Cosmópolis, SP, Brazil.

${ }^{4}$ Sanofi Aventis. Suzano, SP, Brazil.

${ }^{5}$ Quimesp Química. São Paulo, SP, Brazil.

${ }^{6}$ MSD Saúde Animal. São Paulo, SP, Brazil.

${ }^{7}$ Farmaceutici Formenti. Origgio, Italy.

${ }^{8}$ Laboratório Globo. São José da Lapa, MG, Brazil.

Funding. The present report was supported by the Coordenação de Aperfeiçoamento de Pessoal de Nível Superior (CAPES) Código de Financiamento 001.

Declaration of interest. The authors report no conflicts of interest. The authors alone are responsible for the content and writing of paper.

\section{REFERENCES}

1 Bigliardi E., Parma P., Peressotti P., Lorenzi L., Wohlsein P., Passeri B., Jottini S., \& Cantoni A.M. 2011. Clinical, genetic, and pathological features of male pseudo hermaphroditism in dog. Reproductive Biology and Endocrinology. 9(12): 1-7.

2 Bush M.B. 2004. Interpretação de Resultados Laboratoriais para Cínicos de Pequenos Animais. São Paulo: Roca, $384 \mathrm{p}$.

3 Christensen B.W. 2012. Disorders of sexual development in dogs and cats. Veterinary Clinics of North America: Small Animal Practice. 42: 515-526.

4 Foster R.A. 2016. Male genital system. In: Jubb K.V.F., Kennedy P.C. \& Palmer N. (Eds). Pathology of Domestic Animals. 6th edn. St. Louis: Elsevier, pp.465-510.

5 González F.H.D. \& Silva S.C. 2006. Introdução à Bioquímica Clínica Veterinária. 2.ed. Porto Alegre: Editora UFRGS, $364 \mathrm{p}$.

6 Jericó M.M., Kogika M.M. \& Andrade Neto J.P. 2015. Tratado de Medicina Interna de Cães e Gatos. Rio de Janeiro: Roca, 2464p.

7 Lawrence J.A. \& Saba C.F. 2013. Tumors of the male reproductive system. In: Withrow S.J. \& Macewen E.G. (Eds). Small Animal Clinical Oncology. 5th edn. Saint Louis: Elsevier Saunders, pp.557-571. 
8 Lisboa J.L.C. 2015. Causas genéticas relacionadas con anomalias em la diferenciación sexual em animales mamíferos. Revista Cubana De Investigaciones Biomédicas. 34(4): 378-383.

9 Lyle S.K. 2007. Disorders of sexual development in the dog and cat. Theriogenology. 68: 338-343.

10 Maclachlan N.J. \& Kennedy P.C. 2002. Tumors of the genital systems. In: Meuten D.J. (Ed). Tumors in Domestic Animals. 4th edn. Ames: Iowa State Press, pp.84-117.

11 Madureira R., Reis Filho N.P., Santos A.R., Dias A.L., Headley S.A. \& Brum J.S. 2015. Pseudo-hermafroditismo masculino em um cão com seminoma e sertolioma. In: Resumos Congresso Brasileiro de Medicina Veterinária e $1^{\circ}$ Congresso Sul-Brasileiro da ANCLIVEPA (Curitiba, Brazil). pp.1421-1425.

12 Martinuzzi P.A., Franz H.C., Albuquerque T., Martins L.R., Ribeiro C.L.G. \& Meinerz A.R.M. 2016. Entendendo as alterações hematológicas em um quadro de piometra: estudo de um relato de caso. Veterinária e Zootecnia. 23(3): 375-379.

13 Matsuu A., Hashizume T., Kanda T., Nagano M., Sugiyama A., Okamoto Y. \& Hikasa Y. 2009. A case of persistent Müllerian duct syndrome with Sertoli cell tumor and hydrometra in a dog. The Journal of Veterinary Medical Science. 71(3): 379-381.

14 McGavin J. \& Zachary J.F. 2009. Bases da Patologia em Veterinária. 4.ed. Rio De Janeiro: Elsevier, 1496p.

15 Meyers-Wallen V.N., Lee M.M., Manganaro T.F., Kuroda T., MacLaughlin D. \& Donahoe P.K. 1993. Mullerian inhibiting substance is present in embryonic testes of dogs with persistent Müllerian duct syndrome. Biology Reproduction. 48: 1410-1418.

16 Pujar S. \& Meyers-Wallen V.N. 2009. Molecular diagnostic test for persistent Müllerian duct syndrome in Miniature Schnauzer dogs. Sexual Development. 3: 326-328

17 Rizzi T.E., Meinkoth J.H. \& Clinkenbeard K.D. 2010. Normal hematology of the dog. In: Weiss D.J. \& Wardrop K.J. (Eds). Schalm's Veterinary Hematology. 6th edn. Ames: Blackwell Publishing, pp.799-810.

18 Smith F.O. 2006. Canine pyometra. Theriogenology. 66: 610-612.

19 Tannouz V.G.S., Sobrado-Silva M.P.S., Simões C.V. \& Abidu-Figueiredo M. 2014. Síndrome da persistência dos ductos de Müller em cão da raça Schnauzer Miniatura: relato de caso. Archives of Veterinary Science. 19(Supl 2): 6667.

20 Vannucci F.A., Rocha B.D., Issa E.C. \& Guedes R.M.C. 2008. Síndrome da persistência dos ductos de Müller em cão - relato de caso. Veterinária Notícias. 14(1): 71-75.

21 Ververidis H.N., Boscos C.M., Stefanakis A., Saratsis P., Stamou A.I. \& Krambovitis E. 2004. Serum estradiol-17 $\beta$, progesterone and respective uterine cytosol receptor concentrations in bitches with spontaneous pyometra. Theriogenology. 62: 614-623. 